\title{
Biogas Production using Different Wastes: A Review
}

\author{
Sani Aliyu
}

Department of Microbiology Faculty of Natural and Applied Sciences

Umaru Musa Yar"eAdua University, Katsina.

Corresponding author: aliyu.sani@umyu.edu.ng 08068986670.

\begin{abstract}
Biogas as a renewable energy has recently been receiving attention. This is due to its numerous advantages specifically in energy source and waste treatment etc. Several challenges including amount of gas produce, nature of substrates and factors affecting production remains a problem. Hence this review is aimed at investigating different wastes used in biogas production (nature of substrates), amount of gas produced and factors that made a remarkable impact on the outcome of the production. In this review stages of biogas production, purification of biogas, biomass (substrate) pretreatment, classes of wastes used in biogas and their various outcomes, setting the anaerobic digester, factors influencing the rate biogas production and the biogas industry had been extensively reviewed. It was discovered that different substrates produced different amount of biogas. A substrate with less polysaccharide e.g cellulose and higher microbial population produces more gas than substrates with high polysaccharide and less microbial population. This is clearly due to the fact that biogas is a by-product of microbial activities; higher number of the microbes will increase gas production. Substrate with high polysaccharide have slower digestion rate than those with less polysaccharide. Hence these and other factors should be considered before making the choice of substrate to be used.

Key words: Biogas, Substrate, Digestion, Microbial, and Cellulose.
\end{abstract}

\section{INTRODUCTION}

In this century, lack of energy sources calls for intensive research for an alternative or alternatives of energy sources. Recently, studies on waste recovery to produce energy have been discovered as one of such alternatives (Recebli et al., 2015). Biogas production is an environmental friendly process which uses organic wastes to produce energy. A vast number of wastes can be treated with this technology. The main product of this technology (the biogas) is a renewable energy source, while the end product of the anaerobic digestion serves as (the digester residue) manure due to its high nutrients content available to plant. The performance of anaerobic digestion is highly dependent on the characteristics of substrate and the microbial activities involved in different steps of the degradation process. The conversion of organic waste into biogas occurs in three step-wise stages; hydrolysis, acetogenesis and methanogenesis (Ilona et al., 2016).

Biogas is also a key option for short and medium term to mitigate Green House Gas emissions and replace fossil fuels since it can be used as source of heat, electricity and produce transport fuel (Elaiyaraju and Partha, 2016).

The aim of this study is to review biogas production; stages of biogas production, purification of biogas, wastes used in biogas production, how to set up a digester, factors that influence biogas production and different plants used for biogas production at industrial scale.

\section{Biogas Production}

Biogas technology is the biochemical conversion technology of bio-energy (Harka et al., 2010), Biogas is produced by anaerobic decomposition of organic material (agricultural, industrial and domestic wastes) by microorganisms which result in the release of methane $\left(\mathrm{CH}_{4}\right)$, carbondioxide $\left(\mathrm{CO}_{2}\right)$ and hydrogen sulphide $\left(\mathrm{H}_{2} \mathrm{~S}\right)$ (Badiyya, 2018). It has a calorific value of 25.9-30J/M $\mathrm{M}^{3}$ depending on the percentage of methane gas (Segagi et al., 2009). The type of microbes involved in gas production depends on the nature of the substrate used and the environmental conditions (Badiyya, 2018).

The series of stages that occurs in biogas production requires the activities of various microorganisms at different stages. 
The microorganisms include fermentative microbes (acidogens), acetates forming microbes (acetogens), hydrogen producing microbes and methane producing microbes (methanogens). These groups of microorganisms work synergistically to produce biogas as the end product (Mukhtar et al., 2011).

Studies have also shown that there is increasing gas production from the start to the middle of digestion due to increasing of microbes in this phase. However, there is decrease in gas production as the digestion reaches the end due to decrease in number of microbes that produce the gas. Thus, gas production is dependent on the number of microbes (Mukhtar et al., 2011). This is also in accordance with the work of Fatima et al., (2018) who revealed that production of gas was delayed until sixth day because the microorganisms were assumed to be in their lag phase. Increase was recorded in the second and third week which was attributed to the fact that the organisms were in the exponential phase - a phase characterized by growth and proliferation of microbes. Although there are few exceptions to this which may be due to other factors like nature of substrate.

Stages of biogas production

$$
\checkmark \text { Hydrolysis }
$$

This is the process of degrading high molecular weight substances e.g cellulose and starch to low molecular weight. The stage is catalyzed by hydrolytic enzymes.

$\mathrm{nC}_{6} \mathrm{H}_{10} \mathrm{O}_{5}+\mathrm{nH}_{2} \mathrm{O} \rightarrow \mathrm{C}_{6} \mathrm{H}_{12} \mathrm{O}_{6}$

$\checkmark$ Acetogenesis

This is the process of converting $\mathrm{nC}_{6} \mathrm{H}_{12} \mathrm{O}_{6}$ (monomers produced from hydrolysis) to organic acids by acetogens.
$\mathrm{nC}_{6} \mathrm{H}_{12} \mathrm{O}_{12} \rightarrow 3 \mathrm{nCH}_{3} \mathrm{COOH}$

Also $\mathrm{CO}_{2}$ and $\mathrm{H}_{2}$ is converted to organic acids by homoacetogen

$4 \mathrm{H}_{2}+2 \mathrm{CO}_{2} \rightarrow \mathrm{CH}_{3} \mathrm{COOH}+2 \mathrm{H}_{2} \mathrm{O}$

$\checkmark$ Methanogens

Conversions of ethanoic acid, hydrogen and carbondioxide to methane

$\mathrm{CH}_{3} \mathrm{COOH} \rightarrow \mathrm{CH}_{4}+\mathrm{CO}_{2}$

$\mathrm{CO}_{2}+4 \mathrm{H}_{2} \rightarrow \mathrm{CH}_{4}+2 \mathrm{H}_{2} \mathrm{O}$

$\mathrm{CO}_{2}$ can also be hydrolyzed to form carbonic acid which is reduced to methane thus;

$\mathrm{CO}_{2}+\mathrm{H}_{2} \mathrm{O} \rightarrow \mathrm{H}_{2} \mathrm{CO}_{3}$

$4 \mathrm{H}_{2}+\mathrm{H}_{2} \mathrm{CO}_{3} \rightarrow \mathrm{CH}_{4}+3 \mathrm{H}_{2} \mathrm{O}$ (Gumel and Yaro

2013, Segagi et al., 2009).

Purification of biogas

The biogas produced is a mixture of both desirable and undesirable gases. The undesirable gases are majorly $\mathrm{CO}_{2}$ and $\mathrm{H}_{2} \mathrm{~S}$. These gases need to be removed for optimum performance of biogas fuel.

Carbondioxide is removed by passing the gas into lime which result in the formation of calcium carbonate indicated by milky color. Thus;

$\mathrm{Ca}(\mathrm{OH})_{2}+\mathrm{CO}_{2} \rightarrow \mathrm{CaCO}_{3}+\mathrm{H}_{2} \mathrm{O}$

Hydrogen sulphide is removed by passing the gas through a lead acetate solution. Thus;

$\left(\mathrm{CH}_{3} \mathrm{COO}\right)_{2} \mathrm{~Pb}+\mathrm{H}_{2} \mathrm{~S} \rightarrow 2 \mathrm{CH}_{3} \mathrm{COOH}+\mathrm{PbS}$ (Segagi et al., 2009)

Classes of Waste Used In Biogas Production

Different and numerous wastes are used in biogas production. The wastes are classified into three classes

1. Animal waste (this waste from animal dropping and excrete)

2. Industrial waste (This are remnant of materials used in the industries)

3. Crop and domestic waste (Segagi et al., 2009)

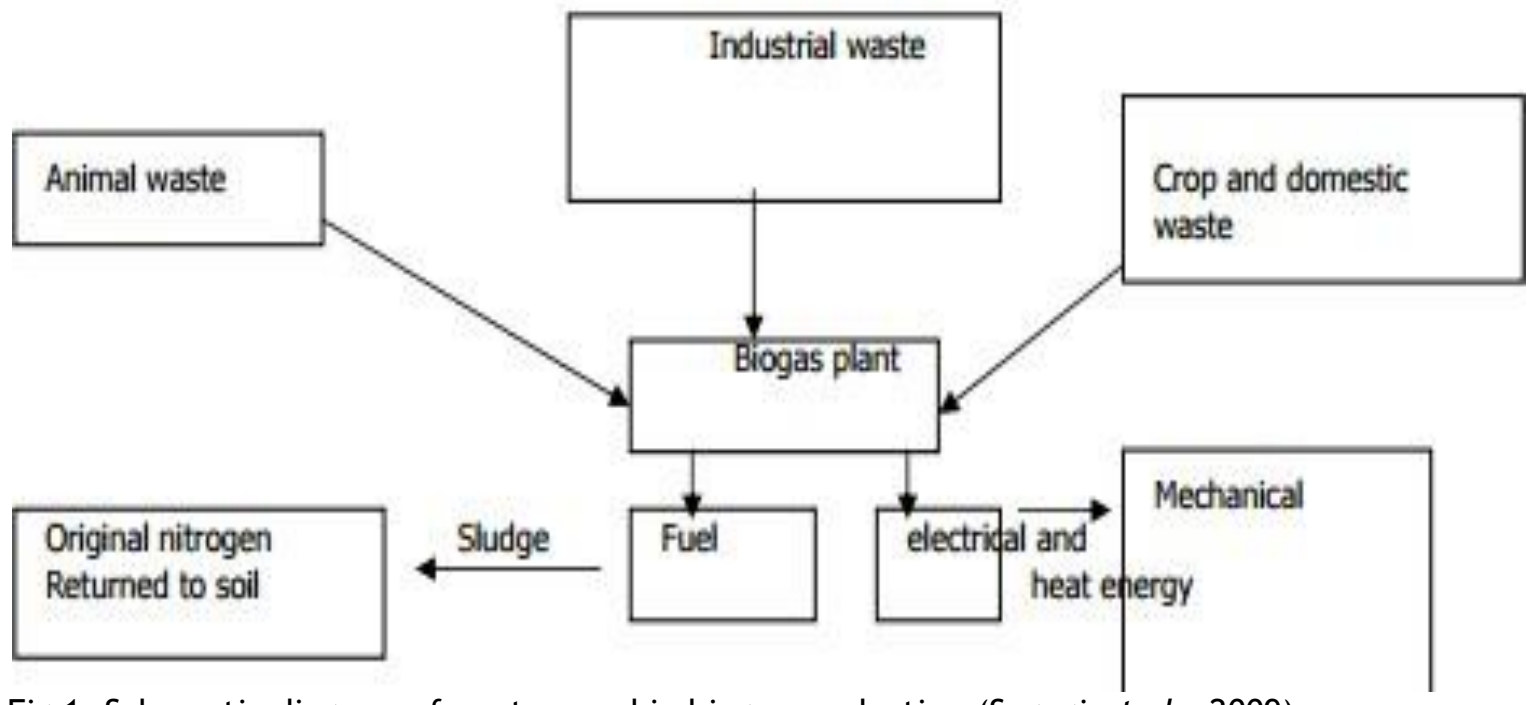

Fig 1: Schematic diagram of wastes used in biogas production.(Segagi et al., 2009). 
Biogas production using animal waste (cow dung)

\section{Digester Design}

Batch type anaerobic digesters were designed in this research using a combination of Karki's Biogas model. The laboratory scale digesters were constructed using five liter empty plastic gallons with three openings one for slurry inlet, the second as gas outlet while the third for slurry collection. The openings of digesters were drilled and fixed with valves. Each valve was further fitted with rubber ring to ensure no air is entering (Tamilarasan and Vimala, 2019).

Slurry preparation

$500 \mathrm{~g}$ of the wastes (cow dung) was weighed and mixed thoroughly with $1000 \mathrm{ml}$ of water in ratio of $1: 2$

\section{Feeding of digesters}

The mode of feeding used was a discontinued feeding (batch feeding). This simply means loading the digester at once and maintaining a closed environment throughout the retention period. The mixture of the waste was poured into the digester and was allowed to undergo anaerobic digestion for retention period 22 days.

\section{Biogas collection}

The biogas was collected by downward displacement of water. The water displacement method of biogas collection is a method in which gas is allowed to replace water at equal volume of water displaced and this will be used to determine the volume of gas produced daily. The biogas produced from the digester was connected to a separate inverted $1000 \mathrm{ml}$ measuring cylinder. The volume displaced was recorded as the volume of gas produced.

Results

The anaerobic digestion of cow dung obtained from Katsina Modern Abattoir generated $400 \mathrm{ml}$ of biogas over the three week digestion period. Gas production reached its peak on the seventeenth day before a gradual fall in the subsequent days. (Fatima et al., 2018).

Biogas production using plant waste (fruits and vegetable)

\section{MATERIALS AND METHODS}

The materials used in this investigation as substrates were waste residue from fruits such as: orange, pineapple and vegetables such as: spinach, pumpkin, all of which were agricultural waste materials (Tamilarasan and Vimala, 2019).

\section{Sampling and Sample Treatment}

The waste materials were collected fresh from various locations around Kano and Kano metropolis, were sun dried for twenty days then oven dried at $110^{\circ} \mathrm{C}$ for $10 \mathrm{hrs}$ before use. UMYU Journal of Microbiology Research
The fruits waste were collected from Naibawa market along Kaduna-Zaria Express way, while the vegetables waste were collected from Yankaba market along Hadejia road and cow dung was collected from Wudil cattle market. The dried samples were grounded using wooden pestle and mortar. By using sieving machine in order to obtain powdered samples which were then stored in a separate black polyethylene bags (Segagi et al., 2009).

Fabrication of Digesters

Five portable digesters were fabricated using three-liter empty plastic gallons, bicycle valves, strip of rubber and polyvinylchloride (PVC) tube of $0.8 \mathrm{~cm}$ diameter. A hole was bored on the cover and the valves were inserted to cover the outlet of the valves. The tube was tightened using a strip of rubber (Segagi et al., 2009).

\section{Preparation of Slurry}

From the dried samples, different slurries were prepared and used for investigations. $200 \mathrm{~g}$ of each substrate was taken and mixed with 1.5 liter of water and each transferred into a separate digester. The biogas produced, from the digester was connected to a separate inverted $1000 \mathrm{~cm}^{3}$ measuring cylinder. The volume of biogas produced from each digester was recorded separately (Mukhtar et al., 2011).

\section{RESULTS}

The biogas production process was investigated for each of the substrate under investigation and was observed that the highest individual production rate was recorded. Pineapple, orange, pumpkin and spinach wastes produced $965 \mathrm{~cm}^{3}, \quad 612 \mathrm{~cm}^{3}, \quad 373 \mathrm{~cm}^{3}$ and $269 \mathrm{~cm}^{3}$ respectively. (Sagagi et al., 2009).

Biogas production using both plant and animal waste (sheep dung and water lettuce)

Sample Collection and processing

Fresh water lettuce was plucked from Sidi Mamman Farm along western bypass road in Sokoto and sheep dung was collected in a clean polythene bags. The fresh samples were collected in a clean polythene bags. The fresh samples were taken to the chemical laboratory research center Sokoto and dried at room temperature for a period of two weeks before grounded into powered form using a pestle and mortar (Nabila and Nawel, 2015).

Preparation of slurry and experience set up Fifty grams $(50 \mathrm{~g})$ of water lettuce was weighed and mixed with $100 \mathrm{~g}$ of sheep dung into a $900 \mathrm{~g}$ empty tin serving as digester $\mathrm{A}$ and another $100 \mathrm{~g}$ of water lettuce was mixed with the $50 \mathrm{~g}$ of sheep dung into digester $B$ which was followed by the addition of $1500 \mathrm{ml}$ ( $1: 10$ waste to water ratio) of water in each digester. www.ujmr.umyu.edu.ng 
The mixture was stirred to obtain homogeneity; the slurry is formed when a saturated solution is formed. Each sample was replicated into three times. All the digesters were sealed with a candle wax in order to check leakage to maintain anaerobic condition.

A horse pipe was connected at the top of each digester by making a hole and covered with epoxy steel gum to avoid leaking of gas. The pipe conveyed the gas from the digester to a measuring cylinder $\left(1000 \mathrm{~cm}^{3}\right.$ capacity) filled with water and placed in an inverted position in a basin filled with water (water displacement method). The cylinder was held firm by retort stand. The gas produced from the digesters was conveyed through the horse pipe to the measuring cylinder which displaced the water downward. The volume of gas produced was measured by the amount of water being displaced from measuring cylinder (Nabila and Nawel, 2015).

\section{RESULTS}

The ratio of 2.1 sheep dung and water lettuce produced more gas $\left(17,983.33 \mathrm{~cm}^{3}\right)$ than ratio 1:2 sheep dung and water lettuce (8, $\left.546.67 \mathrm{~cm}^{3}\right)$. This revealed that digester with higher sheep dung has the greater gas yield. (Sanusi et al., 2017). In conclusion, from the examples it can be deduced that biogas can be produced from animal waste as in example one, from agricultural waste as in example two, or the combination of both as in example three.

Biomass (Substrate) Pretreatment

Biogas from biomass is slow due to certain factors like slow growth of anaerobic microbes, slow hydrolysis, low biodegradability, inhibition due to toxic compounds and poor methanogenesis. As a way of increasing the rate of biogas production, biomass pretreatment is necessary. Pretreatment is done to increase the surface area of the substrate making it more accessible for enzymatic attack hence increasing the rate of biogas yield. However, the effect of pretreatment depends on the substrate and the type of pretreatment method. Pretreatment methods include, mechanical treatment, alkaline treatment, oxidative treatment using ozone, microwave radiation, thermal treatment etc (Tamilarasan and Vimala, 2019).

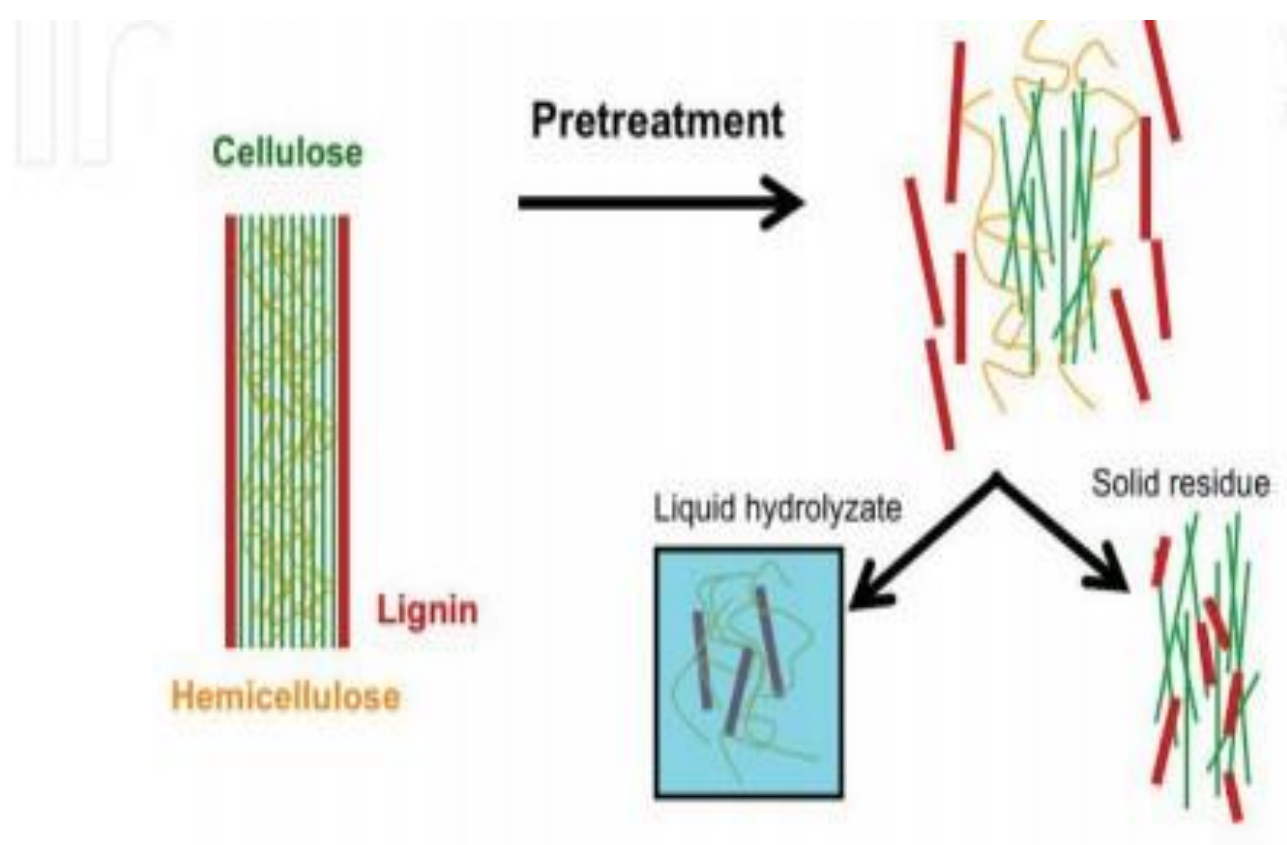

Fig 2: Effect of pretreatment on lignocelluloses biomass (Tamilarasan and Vimala, 2019).

\section{Setting Up the Digester (Reactor)}

Gumel and Yaro (2015), prepared an air-tight reactors for the degradation of slurry and was connected to a gas collector. One third of the reactors were immersed in water bath which was operated at 33 centigrade. The volume of gas produced by each digester was measured by water displacement. 

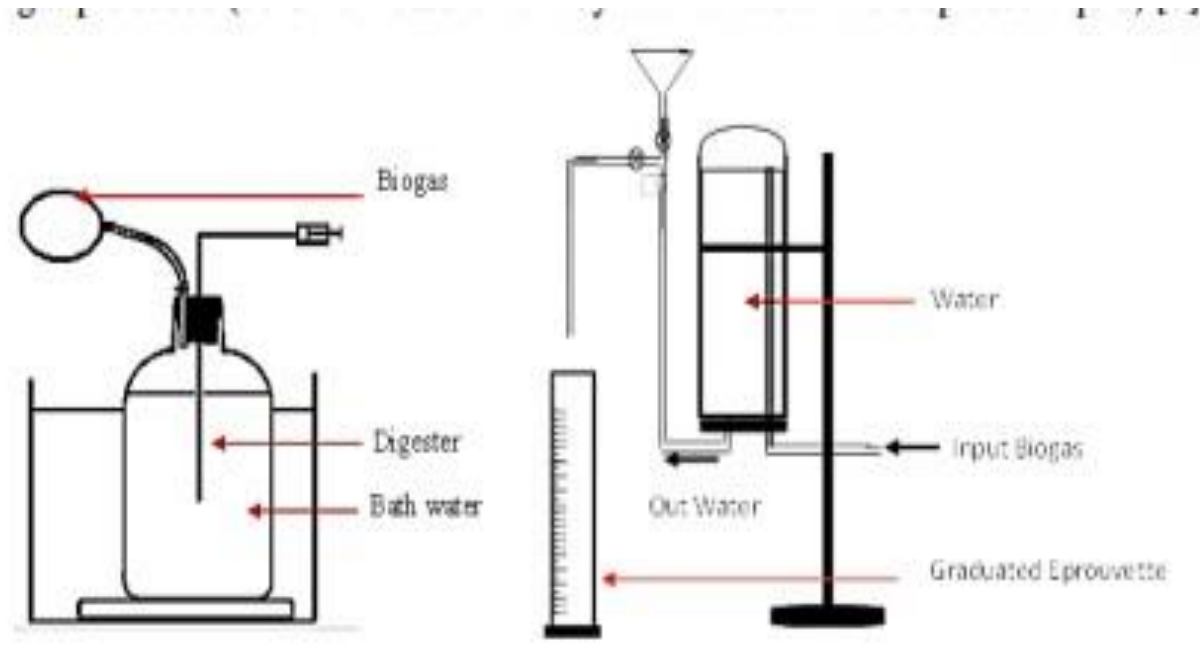

Fig 3: Experimental digester (Nabila and Nawel, 2015)

Badiyya (2018), used milk tins as digesters. The tins were washed using brush, gas produced passed through a channel in form of a hole on the tin. The hole was made on the tin in such a way that will prevent the escape of gas. The gas was collected by downward delivery and was measured delivery and was measured using inverted cylinder.

In another study carried out by Fatima et al., (2018), the digesters were constructed using a 5 liter empty plastic gallon with three openings. The first served as slurry inlet, the second served as gas outlet while the third served as slurry outlet. In the digesters the openings of the digester were drilled and fixed with valves. Each valve was further fitted with rubber ring to ensure it is air tight. In this set up, gas was collected by downward displacement of water. This method of gas collection is one that gas is allowed to replace water at the same volume of water displaced and this was used to determine the volume of gas that was produced daily. The volume of displaced water was recorded as the volume of gas produced.

From these studies, it can be deduced that the digesters can be constructed in different ways but the method of gas collection was the same in all. The difference in digester construction is due to the differences in the aim of the studies. For example, Fatima et al., (2018) used a digester that has slurry outlet because one of the things studied was the total bacterial counts before and during the digestion process. Hence, this requires more than one outlet for gas only. In contrast, the studies carried out by Badiyya (2018) only had one gas outlet because; the study was not aimed at the bacterial count but only gas production hence the need for only gas outlet without slurry outlet. Gumel and Yaro (2015), made an air-tight container and placed in a water bath to maintain the temperature is a major factor of gas production.

Factors That Influence the Rate of Biogas Production

Certain factors influence the rate at which biogas is produced as well as the amount. Below are some of these factors;

The nature of substrate

Experiment has shown that different substrates produced different amount of biogas. The is traceable to the fact that different substrates has different composition. This is in concordance with the study of Badiyya (2018), the comparative analysis involved sugarcane bagasse and cow dung. In this study, it was observed that cow dung had a greater yield due to the presence of high number of microbes, presence of growth factors and less sugar concentration compared to bagasse. The low yield of biogas from the bagasse was attributed to high carbohydrate which resulted in difficulty in hydrolysis stage (Badiyya, 2018).

\section{Temperature}

Temperature is a key factor in biogas production. This is in concordance with the study of Fatima et al., (2018). In this study, the mean daily record of slurry temperature during the digestion process was taken. The temperature remained at mesophilic temperature range (25-33) throughout the study. The lowest temperature reading of 24.25 centigrade was obtained on the eleventh day while the highest of $30.5,32.5$ and 31.0 Celsius were recorded on the sixteenth, seventeenth and eighteenth day of the digestion respectively. It was observed that there was highest yield of biogas on the seventeenth day; the same day the temperature was highest (32.5 Celsius) as depicted in the graph plot below (Fatima et al., 2018). 


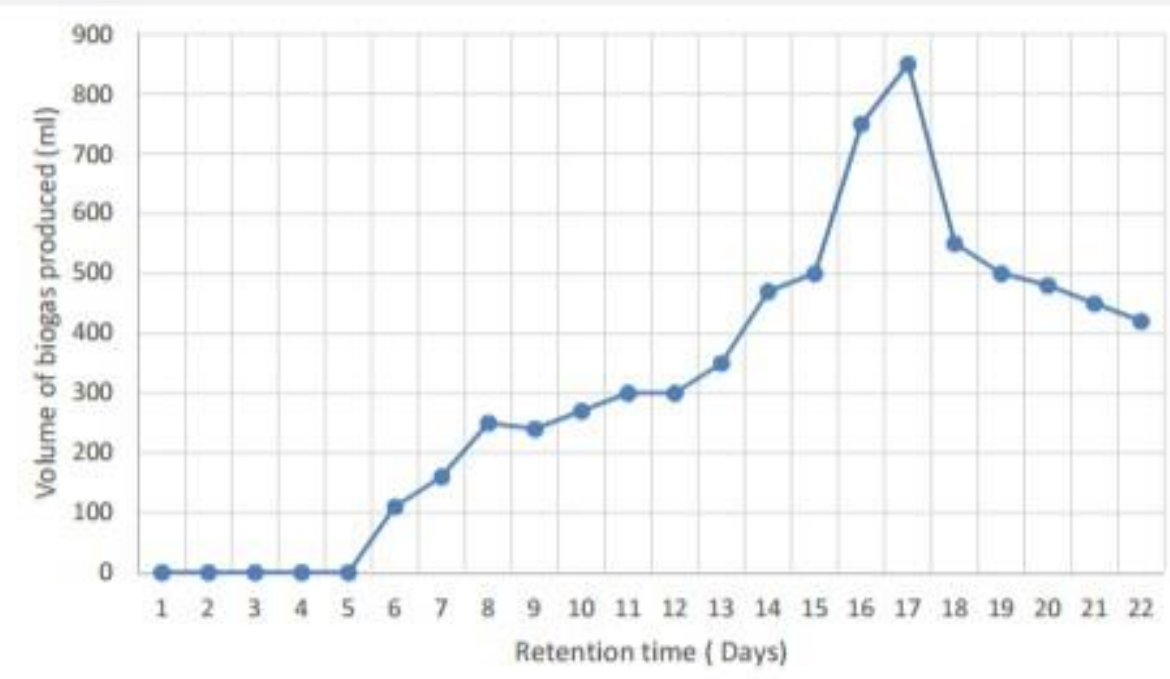

Fig 4: Graph sketch of daily gas production (Fatima et al., 2018)

\section{$\mathrm{pH}$}

According to a studies carried out by Sanusi et al., (2017), pH is one parameter that affect the rate of biogas production as microbes involved operate within a neutral $\mathrm{pH}$. The two substrates used, cow dung and water lettuce were within the range value (7.2-7.3). This is also in accordance with the work of Fatima et al., (2018). In the two studies, it was discovered that the initial $\mathrm{pH}$ decreases with time; from 7.89 to 6.51 .

Slurry concentration

In an experiment carried out by Gumel and Yaro (2013), chicken droppings of different concentration were used. In the experiment, three slurries were prepared $\left(50 \mathrm{~g} / 625 \mathrm{~cm}^{3}\right.$, $100 \mathrm{~g} / 625 \mathrm{~cm}^{3}$ and $150 \mathrm{~g} / 625 \mathrm{~cm}^{3}$ ) were placed in digesters. This is produced a varying volume of gasses. This is also in concordance to the work of Sanusi et al., (2017), in this experiment sheep dung and water lettuce was used. The concentration ratio was varied. In one digester the ratio of sheep dung and water lettuce was 2:1 and another digester the ratio was 1:2. Amount of gas produced was observed to be different due to slurry concentration difference. It was observed that the combination ratio of 2:1 produced more gas $\left(17,983.33 \mathrm{~cm}^{3}\right)$ compared to the combination ratio of $1: 2\left(8546.67 \mathrm{~cm}^{3}\right)$.

\section{Stirring}

Digesters are stirred or shake periodically on daily basis to ensure proper digestion (Gumel and Yaro 2013).

\section{Carbon to Nitrogen ratio}

In the study of Sanusi et al., 2017, proximate analysis of sheep dung revealed 43.06 carbon to nitrogen ratio while it was 25.47 for water lettuce. This might be one of the contributing factors to high yield of biogas in the digester with higher ratio of sheep dung. The gas produced from the digester with higher ratio of sheep dung was $17,983.33 \mathrm{~cm}^{3}$ while gas produced from digester with lower sheep dung ratio was $8546.67 \mathrm{~cm}^{3}$. Hence Carbon to Nitrogen ratio should be put into consideration when selecting a suitable substrate (Badiyya, 2018).

\section{Sample processing}

Sample processing means digesting or crushing the substrate before introducing it to the bioreactor. It is a pretreatment process. Segagi et al., (2009) carried out a comparative analysis for digested and undigested substrate. The substrates were cow dung, pineapple, orange, pumpkin and spinach. Higher production of biogas was observed in digested substrate than the undigested ones. The exception was orange whose amount of gas production was equal for both digested and undigested substrate. Hence digestion of substrate is a good pretreatment which enhances higher yield of biogas production. 


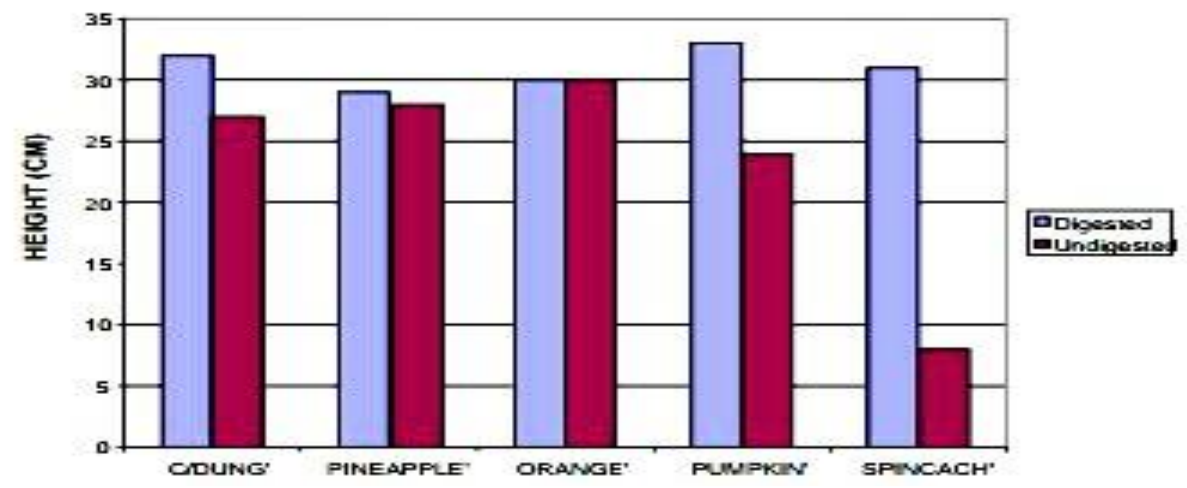

Fig 5: comparative gas production of digested and undigested substrates (Segagi et al., 2009)

\section{Biogas Industry}

Plants are classified into two based on the type of the digested substrates, the technology applied or size of the plant. They are:

1. Large scale, joint co-digestion plants

2. Farm scale plants (Ilona et al., 2016)

Joint co-digestion plants

Co-digestion is the concurrent digestion of a mixture of two or more substrates. This is achieved when there is coexistence of different types of substrate in the same geographical area. This enables integrated management and environmental benefit e.g energy savings, recycling of nutrients back to agricultural land and reduction or carbon dioxide emission.

Co-digestion may enhance the performance of anaerobic digestion (AD) due to the different properties of waste treated together. The properties may give rise to positive synergism established in the digester by provoking a balanced nutrient supply and sometimes by increasing the moisture content in the digester. The farm scale biogas plants

Farm scale digester is been used in Germany, Switzerland, UKetc. Animal manure and energy crops are the most important aspect to biogas production is to reduce leaching of nutrients from agricultural lands to aquatic environments. As a result of this, farm scale plants are usually established at large pig farms, which is aimed at solving the problems caused by excessive slurry production.

The most recent and common digester used in farm scale application is a vertical tank made up of concrete and equipped with a flexible membrane and light roofing which makes it possible to be used as a digester and gas storage tank at the same time. The average size of the digester is typically from hundreds to thousands $\mathrm{m}^{3}$ (Ilona et al., 2016).

\section{CONCLUSION}

Biogas as a source of renewable energy can be produced from vast organic wastes ranging from plant wastes, animal wastes, domestic wastes etc as reviewed in this paper. Certain factors like temperature, $\mathrm{pH}$, nature of substrate, carbon to nitrogen ratio influence the rate and amount of biogas produced. These factors should be put into consideration during biogas production.

A very interesting importance of biogas production to the environment is that, it is an indirect means of clearing and treating environmental waste and in the process waste is turned to wealth. The useless waste used in biogas production produces a useful renewable energy that can be used as source of heat, electricity or fuel. This serves as a good replacement to fossil fuels that cause environmental hazards like greenhouse effect.

\section{RECOMMENDATIONS}

1. As a way of overcoming the challenges in energy generation from fossil fuel, the use of biogas should be encouraged in the public by enlightening them on the importance of biogas over other sources of energy.

2. Government should make it available to the society as a way of encouraging its used.

3. Large scale of biogas which is sufficient enough for the public should be made available. This can be achieved by constructing more biogas plant.

4. Scientific research should not just stop at experimental level of biogas production but should be extended to the industrial level in other to produce biogas at a larger scale. 


\section{REFERENCES}

Badiyya, H. M. (2018). Comparative study of biogas production from sugarcane bagasse and cow dung. UMYU Journal of Microbiology Research, 3(2), pp. 127-131.

Fatima, M., Aliyu, A., Ummasalma, A. S. and Hadiza, G. (2018). Biogas production from cow dung for substantial energy generation. UMYU Journal of Microbiology Research 3(1), pp. 81-85.

Gumel, S.M. and Yaro, M.N. (2015). Generation of biogas from maize cob and analysis of the combustible component of the biogas using flame ionization detector (FID). Dutse journal of Pure and Applied sciences 1(1), pp 90-95

Gumel, S.M. and Yaro, M.N. (2013). Production and analysis of biogas from varying concentrations of chicken droppings. Biological and Environmental Sciences Journal for the Tropics 10(3), pp. 109110.

Harka, M. L., Amrit, B. K. and Jagan, N. S. (2010). Biogas production from anaerobic digestion of biodegradable household wastes. Nepal Journal of Science and Technology 11, pp. 167172.
Ilona, S.H., Meisam, T., Keikhosro, K. and Rajeev k. (2016). Recent update on biogas production - a review. Biofuel research journal 10, pp. 394-402.

Nabila, L. and Nawel N. (2015). Comparative study for biogas production from different wastes. International Journal of Bio-Science and Bio-Technology, 7(3), pp. 39-46.

Elaiyaraju P. and Partha N. (2016). Studies on biogas production by anaerobic process using agro industrial wastes. International Journal of Bio-Science and Bio-TechnologyVol. 62, pp 73-82.

Sanusi, A., Abdulkadir, B. and Baki, A.S. (2017). Comparative Study on the Efficacy of Biogas Production from Mixture of Animal Waste and Water Lettuce. UMYU Journal of Microbiology Research 2(2), pp. 125-128.

Segagi, B. S., B. Garba and N. S., Usman. (2009). Studies on biogas production from fruits and vegetable waste. Bayero Journal of Pure and Applied Sciences, 2(1), pp. 115-118.

Tamilarasan, K. and Vimala, E. A. (2019). Biomass pretreatment for enhance of biogas production.Bayero Journal of Pure and Applied Sciences, 3(1), pp. 215-218. 